\title{
Domestication of Dyera polyphylla (Miq.) Steenis in peatland agroforestry systems in Jambi, Indonesia
}

\author{
Hesti L. Tata $\cdot$ Meine van Noordwijk $\cdot$ Jasnari $\cdot$ \\ Atiek Widayati
}

Received: 23 March 2015/Accepted: 6 August 2015/Published online: 25 August 2015

(C) The Author(s) 2015. This article is published with open access at Springerlink.com

\begin{abstract}
As part of a broader pattern of recovery after decline called forest transition, tree cover and carbon stocks have increased through agroforestry systems in many parts of Indonesia. The associated tree diversity transition implies that only the most useful parts of local tree flora are promoted. Swampland jelutong, Dyera polyphylla, has been domesticated in peat areas Jambi province, Indonesia. We discuss jelutong domestication in two coastal districts, referring to seven steps in a gradual change from products collected from communal natural forests to specific genotypes managed on private farms. Domestication of $D$. polyphylla in Jambi was in the initial stages three decades ago, when jelutong latex was directly tapped from the trees in its natural habitat of peat swamp forests. Tapping jelutong latex stopped in 2005 following the national regulation taxing forest products. Some farmers then started jelutong cultivation, motivated by the profitability of trading jelutong latex in the past. Our on-farm study showed that jelutong can be planted in various mixed agroforestry systems, with rubber, coffee or oil palm as dominants.
\end{abstract}

H. L. Tata $(\bowtie)$

Forest Research and Development Agency, Jalan Gunung Batu 5, Bogor 16610, Indonesia

e-mail: h.tata@cgiar.org; hl.tata@gmail.com

H. L. Tata · M. van Noordwijk · Jasnari · A. Widayati World Agroforestry Centre (ICRAF) Southeast Asia Regional Office, Jalan CIFOR, Sindangbarang Jero, Bogor 16680, Indonesia
Planted jelutong with good farm management showed diameter growth rates of 1.3 to $1.9 \mathrm{~cm} \mathrm{year}^{-1}$. Onfarm trials showed that dolomite as soil ameliorant did not affect diameter growth, but had some effect on height. Jelutong planted between young oil palm had the best performance, while jelutong that was underplanted in mature rubber gardens grew slowly. Slow market revival currently constrains further tree domestication of jelutong.

Keywords Cultivation - Jelutong · Sumatra · Livelihood · Tapping latex

\section{Introduction}

Many plants have co-evolved with involuntary animal dispersal agents, but it is not clear where deliberate rather than accidental seed dispersal started in the evolution of our species, as a first step towards plant domestication by humans (Herrera 2002). The start of agriculture as a primary source of food production dates back to the Pleistocene/Holocene transition, some 10,000 years ago at the end of the ice age (Larson et al. 2014). While 353 species have been listed as globally domesticated food crops (Meyer and Purugganan 2013), Simons (1996) reported that more than 2500 tree species have been planted in agroforestry systems all over the world, representing about $3 \%$ of the global tree flora. The negative effects of human presence on seed dispersal by animals as a result of 
forest fragmentation, hunting, and selective logging may have increased the need for an active human role in the dispersal of desirable species (Markl et al. 2012). As currently understood, domestication of trees (and other plants) is a gradual process that involves social, ecological and institutional aspects of the way humans relate to the plants as a desirable part of modified (agro)ecosystems (Wiersum 1996). Tree domestication is part of the tree diversity transition (Ordonez et al. 2014) that accompanies forest or tree cover transitions (van Noordwijk et al. 2012; van Noordwijk and Villamor 2014); after a phase of declining tree cover and tree diversity, new forests, agroforests and more intensively managed agroforestry systems emerge, where trees with high utility dominate, usually combining elements of the local flora with trees introduced from elsewhere. The relative share of trees remnant of previous vegetation, trees spontaneously established and those (trans)planted varies among the agroforestry systems of the world (Ordonez et al. 2014; Santos-Martin et al. 2011). Forest domestication and increased control over and management of forests, generally precedes the specific steps of tree domestication (Michon and De Foresta 1996).

Domestication of tree species usually starts with commercial interest in products-timber or nontimber-that are derived from natural forests. Commercial interest may be based on local markets, as is the case with Dacryodes edulis and Irvingia gabonensis in Cameroon and Nigeria (Leakey et al. 2004). If products are only extracted for local use, however, it is less likely that a sudden increase ('boom') in use leads to the exhaustion of local resources, as has happened with many non-timber forest products (Prance 1994). While technically it is a small step to shift from accidental to deliberate seed dispersal, the economics is challenging of a transition from a situation where human labour is spent only for harvesting products to one that involves planting, tending and caring for young trees many years before they yield commercial products (Martini et al. 2012). Only when the search time for products in the wild equals, per unit product, the discounted time spent on tree growing, will the domestication hurdle of controlled tree reproduction be overcome and be left under the control of market forces (Mpanda et al. 2014). Farmer-driven domestication is led by subsistence use and local markets, such as nutrition and food (Leakey et al. 2004; Schreckenberg et al. 2006). It can coexist with market-led processes elsewhere where actors further down the value chain invest and/or with public sector support for underpinning research (Simons and Leakey 2004).

Tree domestication is defined as a continuous action that comprises species selection, production, management and adoption of desirable germplasm to product marketing (Roshetko and Evans 1999). In the process, humans become the most important agent of tree reproduction through roles as agents of seed dispersal, selection and environmental modification (Larson et al. 2014). A typical sequence of events in tree domestication is: A. Recognized market value of a tree product; B. Depletion of wild stocks, especially where harvesting has negative effects on tree growth or reproduction; C. Emergence of institutions to regulate the use of wild resources, slowing down but not reversing the degradation; D. Active seed dispersal, transfer of wildings, cuttings or nurserybased tree planting in a part of the landscape where the planter can expect to benefit from future production; E. Genetic selection of superior genotypes, with fitness determined by the 'new' environment in which the plants are grown, early production (precociousness), quantity and quality of products; F. Development of vegetation and soil management techniques that suit the desirable species; and G. Organized linkages along the value chain that secure future demand at prices that justify intensified production.

Here, we will use this generic frame (steps A to G) to analyze the early stages of domestication of jelutong-one of the few trees that grows in peat swamp forests in Southeast Asia and that has sufficient economic potential to support local livelihoods without major habitat alteration-as an alternative to the introduction of oil palm (Elaeis guineensis) and other commercial crops that require drainage of the peat and hence cause greenhouse gas emissions to the atmosphere. Effective control of peatland emissions without a decrease in human livelihood options requires alternatives candidates for low emission development (van Noordwijk et al. 2014). Dyera polyphylla (Miq.) Steenis (synonym: Dyera lowii Hook f.) is locally known as jelutong and has long been appreciated for its latex, obtaining importance in global trade in the mid nineteenth century (Williams 1963). It grows naturally in peat swamp forests and is known as swampland jelutong. A related species, Dyera costulata Hook.f, grows on mineral soils and is locally 
known as dryland jelutong (Middleton 2004). The natural distribution of both species covers Peninsular Malaysia, Sumatra, and Borneo. Swampland jelutong grows well in submerged locations and survives with a high water table, as it has pneumatophore roots that allow atmospheric gas exchange for living root tissue. As a species belonging to the Apocynaceae family and relative of oleander, D. polyphylla has white sap which was used in the past as a basic material for chewing gums (Williams 1963). Jelutong latex differs from rubber (Hevea brasiliensis) latex, as it has a lower resin content, which affects latex elasticity (Jayanthy and Sankanarayan 2005). Due to this characteristic, it can be used for insulation material and in medical devices, including tubings and condoms (Williams 1963). The light and bright wood of jelutong supports various industries, such as pencils, wooden toys, ceiling materials and packing cases among others (Middleton 2004; Lemmens et al. 1995). The recognized market value (Step A) induced over-exploitation of the wild stocks of $D$. polyphylla trees in its natural habitat (Step B), although data on the remaining wild populations of $D$. polyphylla in Indonesia is very limited. We have explored experience with the subsequent steps of the tree domestication pathway, based on case studies in the peat swamps of Jambi, on the east coast of Sumatra.

The objectives of the research reported here were to:

1. Describe and analyze the progression on the domestication steps A to $G$ listed above, to understand how bottlenecks have been overcome and what currently limits further progress in the use of D. polyphylla as a key to low-emission land uses in tropical peat swamps;

2. Experimentally test the site management practices (step F) that have been proposed for more intensive use of peatlands for jelutong production, in the form of dolomite as a 'soil ameliorant';

3. Prioritize the next steps to promote wider use of $D$. polyphylla if a long-term market interest (Step G) can be secured.

\section{Materials and methods}

Data collection targeted information on the eight steps of a domestication chain, which consists of:
A. Recognized market value of the tree product;

B. Depletion of wild stocks;

C. Emergence of institutions to regulate use of wild resources;

D1. Active seed dispersal, transfer of wildings, use of cuttings or nursery-based tree planting;

D2. Benefit expectation of the planters from future production in controllable parts of the landscape;

E. Genetic selection of superior genotypes;

F. Tree growth and soil management techniques; and

G. Organized linkages along the value chain.

Information was collected using a combination of spatial analysis, focus group discussions, key informant interviews and experimentation in the study area.

Study area

The study was conducted in the two coastal, peatland districts of Jambi province, Tanjung Jabung Barat (commonly referred to using the acronym Tanjabar) and Tanjung Jabung Timur (commonly referred to using the acronym Tanjabtim). Jambi province has more than 0.6 million ha of peatlands (Ritung et al. 2011), out of a total for Indonesia of approximately 15 million ha (Ritung et al. 2011). Nine villages where jelutong has been planted and used were purposely selected as study sites-Rawa Sari, Sungai Aur and Sidomukti in Tanjabtim; and Senyerang, Teluk Nilau, Bram Itam, Mekar Jaya, Muntialo Jaya and Teluk Kulbi in Tanjabar (Fig. 1). The GPS coordinates of all villages are shown in Table 1 . These villages were accessible to the researchers and were expected to represent a range of site histories and current population composition with people with historical land claims, long-term and recent migrants (Galudra et al. 2014).

Replicates of a planting trial were established as five 'demo-plots' in four villages in Tanjabar-Teluk Kulbi, Muntialo Jaya, Teluk Nilau and Mekar Jaya. The demo-plots were established in existing farming systems-coffee, rubber, oil palm and shrubs on peatlands.

Data collection

A. Recognized market value of the tree product Local ethnobotanical knowledge on the 


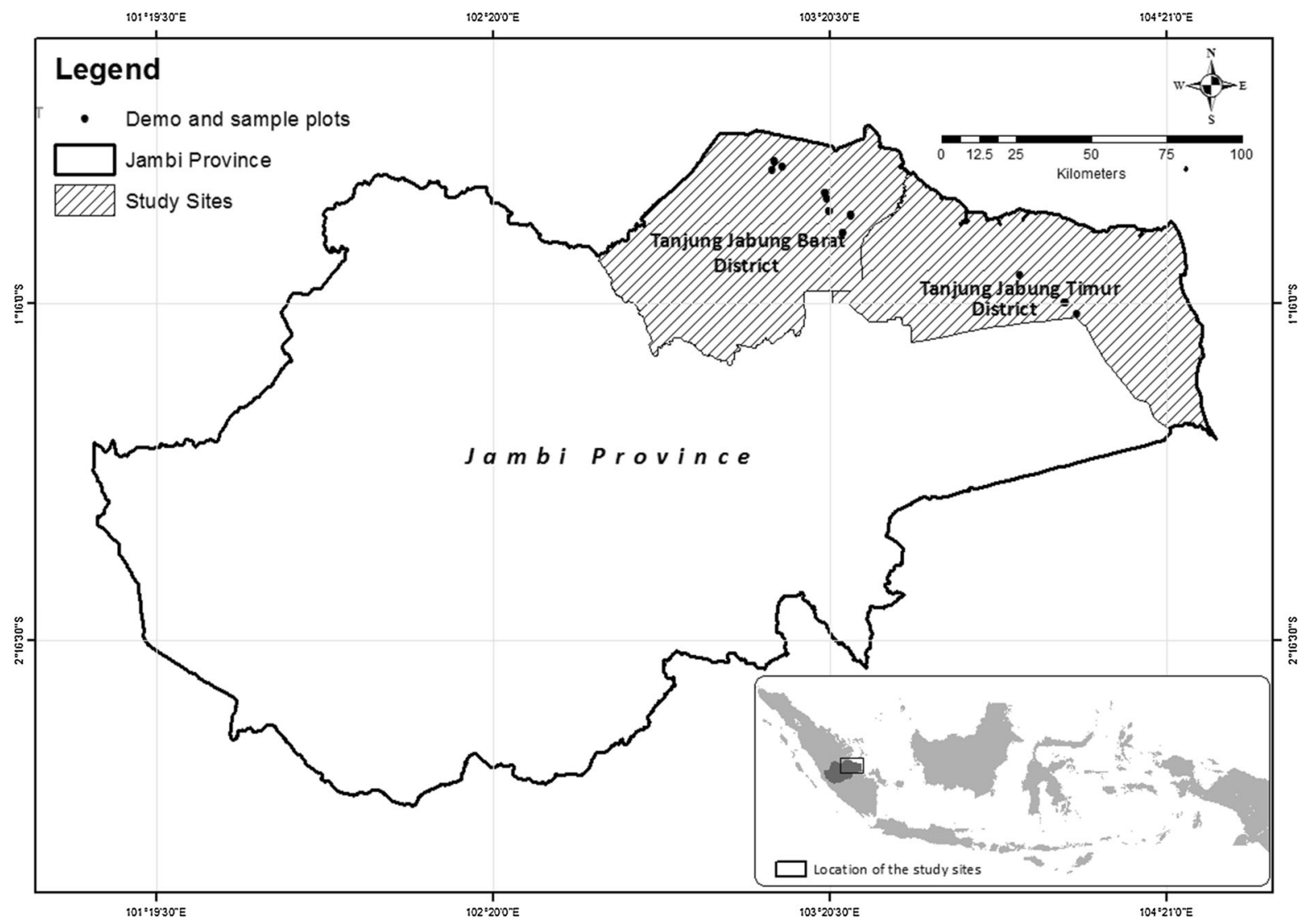

Fig. 1 Study sites of Dyera polyphylla domestication in Tanjung Jabung Barat and Tanjung Jabung Timur districts, Jambi province, Indonesia

characteristics of jelutong and planting and tapping practice were assessed following the Rapid Appraisal of Agroforestry Practices, Systems and Technology (RAFT) protocol (Joshi et al. 2013). Twenty farmers and tappers of jelutong from 5 villages in Tanjabar and Tanjabtim were selected and interviewed as respondents. The respondents interviewed included those who had experience with tapping jelutong latex in the past, and farmers who already practised planting jelutong seedlings.

B. Depletion of wild stocks was assessed through a survey and inventory in remnant secondary peat swamp forests in Tanjabar and Tanjabtim. Non-permanent rectangular plots in Bram Itam, Tanjabar (total plot area $=0.7 \mathrm{ha}$ ) and Rawa Sari, Tanjabtim (total plot area $=$ $0.2 \mathrm{ha}$ ) were established and measured to determine the diameter distribution in wild jelutong stands. All jelutong tree with diameter at the breast height $(\mathrm{dbh})>5 \mathrm{~cm}$ were measured and counted. The Senyerang and Rawa Sari forests are commonly known as sources of jelutong seed and seedlings in Jambi.

C. Emergence of institutions to regulate use of wild resources

Tappers and middlemen of jelutong latex from the two districts were interviewed regarding their expectations on current and future jelutong latex markets. Some constraints on development of on-farm jelutong may result from the current Indonesian regulation on the use of wild resources, which we analysed (Sofiyuddin et al. 2012; Agung et al. 2012).

D1. Active seed dispersal, transfer of wildings, use of cuttings or nursery-based tree planting 
Table 1 Study sites of jelutong planting in Tanjung Jabung Barat and Tanjung Jabung Timur districts, Jambi province, Indonesia

\begin{tabular}{|c|c|c|}
\hline Site location (GPS coordinates) & $\begin{array}{l}\text { Domestication } \\
\text { level* }\end{array}$ & Note \\
\hline Senyerang, Tanjabar & Wild & Patchy secondary forest \\
\hline$\left(0^{\circ} 50^{\prime} 21.6^{\prime \prime} \mathrm{S}-103^{\circ} 9^{\prime} 55.2^{\prime \prime} \mathrm{E}\right)$ & Planted & $\begin{array}{l}\text { Tree age: } 6 \text { year after planting from local seedling } \\
\text { production-growth data collection }\end{array}$ \\
\hline Mekar Jaya, Tanjabar & Enriched & Cultivation from unknown seedlings source \\
\hline$\left(0^{\circ} 59^{\prime} 19.99^{\prime \prime} \mathrm{S}-103^{\circ} 20^{\prime} 11.04^{\prime \prime} \mathrm{E}\right)$ & Planted & $\begin{array}{l}\text { Tree age: } 2 \text { year after planting in a demo-plot (BO and KS } \\
\text { plots). On-farm experiment used known and selected } \\
\text { seedlings source }\end{array}$ \\
\hline Teluk Nilau, Tanjabar & Enriched & Cultivation from unknown seedlings source \\
\hline$\left(0^{\circ} 51^{\prime} 15.55^{\prime \prime} \mathrm{S}-103^{\circ} 11^{\prime} 46.26^{\prime \prime} \mathrm{E}\right)$ & Planted & $\begin{array}{l}\text { Tree age: } 2 \text { year after planting in a demo-plot (MS plot). } \\
\text { On-farm experiment used known and selected seedlings } \\
\text { source }\end{array}$ \\
\hline Bram Itam, Tanjabar & Wild & Patchy secondary forest \\
\hline$\left(0^{\circ} 55^{\prime} 57.1^{\prime \prime} \mathrm{S}-103^{\circ} 19^{\prime} 47.3^{\prime \prime} \mathrm{E}\right)$ & Enriched & $\begin{array}{l}\text { Rehabilitation of peat reserve forest ( } 4 \text { year) and wild } \\
\text { distribution in patchy secondary forest }\end{array}$ \\
\hline $\begin{array}{l}\text { Teluk Kulbi, Tanjabar } \\
\left(1^{\circ} 0^{\prime} 2.68^{\prime \prime} \mathrm{S}-103^{\circ} 24^{\prime} 7.14^{\prime \prime} \mathrm{E}\right)\end{array}$ & Planted & $\begin{array}{l}\text { Tree age: } 2 \text { year after planting in a demo-plot (MS plot). } \\
\text { On-farm experiment used known and selected seedlings } \\
\text { source }\end{array}$ \\
\hline $\begin{array}{l}\text { Muntialo Jaya, Tanjabar } \\
\left(1^{\circ} 3^{\prime} 10.1^{\prime \prime} \mathrm{S}-103^{\circ} 22^{\prime} 38.61^{\prime \prime} \mathrm{E}\right)\end{array}$ & Planted & $\begin{array}{l}\text { Tree age: } 2 \text { year after planting in a demo-plot (HR plot). } \\
\text { On-farm experiment used known and selected seedlings } \\
\text { source }\end{array}$ \\
\hline $\begin{array}{l}\text { Rawa Sari, Tanjabtim } \\
\left(1^{\circ} 15^{\prime} 44.04^{\prime \prime} \mathrm{S}-104^{\circ} 2^{\prime} 41.54^{\prime \prime} \mathrm{E}\right)\end{array}$ & $\begin{array}{l}\text { Enriched } \\
\text { Planted }\end{array}$ & Domestication (5 year) and wild distribution \\
\hline $\begin{array}{l}\text { Sungai Aur, Tanjabtim } \\
\left(1^{\circ} 17^{\prime} 47.94^{\prime \prime} \mathrm{S}-104^{\circ} 4^{\prime} 44.59^{\prime \prime} \mathrm{E}\right)\end{array}$ & Domesticated & Plantation (16 \& 20 year) and domestication \\
\hline $\begin{array}{l}\text { Sidomukti, Tanjabtim } \\
\left(1^{\circ} 10^{\prime} 40.80^{\prime \prime} \mathrm{S}-103^{\circ} 54^{\prime} 5.25^{\prime \prime} \mathrm{E}\right)\end{array}$ & Enriched & Domestication (1.5 year) \\
\hline
\end{tabular}

* Based on Martini et al. (2012) domestication levels can be described in four categories: (i) wild (uncontrolled, open access gathering or controlled gathering of wild tree products, without management); (ii) enriched (collection of wild tree products with protective tending of valued tree species, and selective cultivation of valued trees by in situ regeneration); (iii) planted (cultivation of wild tree species in artificially established plantation); (iv) domesticated (cultivation of domesticated tree crops in intensively managed plantation)

Propagation of D. polyphylla has been practised widely in Jambi. We assessed the propagation techniques of jelutong based on observations in the field and interviews with key persons, who have practical experience. Non-permanent rectangular plots at five sites of planted jelutong with different age classes were established to measure the diameter growth of jelutong trees and to calculate the growth rate.

D2. Benefit expectation of the planters from future production in controllable parts of the landscape
An overview of tenure status and conflicts between the local community, migrants, private sector and government agencies in the area is provided by Galudra et al. (2014). We surveyed jelutong plantations and their tenure status in the area, with the oldest known having been established in 1992 in Sungai Aur, Tanjabtim, while the newest plots of rehabilitation in the peat forest reserve of Bram Itam, Tanjabar were established in 2006-2007 as part of interactions between the local forestry agency and farmers.

E. Genetic selection of superior genotypes 
Genetic characterization of swamp jelutong from Jambi and Kalimantan has not been published yet but is ongoing. Basic tree improvement studies have started with the collection of germ plasm (Franton 1996), through the collection and planting of two different gene pools of jelutong from Senyerang and Rawa Sari. The seedlings from the two sources were planted separately in different demo-plots in Tanjabar. These sites can be used for further tree improvement study of jelutong in Jambi.

F. Tree growth and soil management techniques This step was assessed through the development of the demo-plots in existing tree crop systems. Jelutong seedlings were collected from Senyerang and Rawa Sari and distributed to the five plots. Senyerang's seedlings were 6-7 months old after seedling transplanting in the nursery and those from from Rawa Sari 12 months. The Senyerang's seedlings were planted in MI and HR plots, while Rawa Sari's seedlings were planted in three other plots (KS, BO and $\mathrm{KD}$ ). The planting spacing of jelutong varied between plots and follows that of the existing planted crops, such as $8 \mathrm{~m} \times 8 \mathrm{~m}$ on two farms of oil palm farms (BO and $\mathrm{KS}$ ) and a farm derived from shrub (HR); $5 \mathrm{~m} \times 5 \mathrm{~m}$ on a rubber farm and $3 \mathrm{~m} \times 3 \mathrm{~m}$ on a coffee farm. Dolomite $\left(\mathrm{CaMg}\left(\mathrm{CO}_{3}\right)_{2}\right)$ was tested as a soil ameliorant at a rate of $0,25,50,75$ and 100 g per seedling. The jelutong seedlings were planted in May 2012 by the participating farmers. To prevent disturbance by wild pigs that often are attracted to soil disturbed for tree planting, a small protective cover was placed over each seedling, using available resources, such as the midribs of oil palm, Areca nut, coconut, and bark of Areca nut. One farmer used a plastic net that was installed on the perimeter of the farm. Farm management was left to the farmers' choice. Growth measurements of the stem diameter and height of each seedling were collected every 6 months for four successive measurements.

Field assessment obtained data on the microclimatic conditions including solar radiation, temperature of air and soil, and humidity of air and soil. Each plot was measured three times in
1 day, to obtain the daily mean of microclimatic data. Solar radiation was measured using a Lutron LX-1102 lux meter, air temperature and humidity were measured using a TFA model 4928D thermo hygrometer, soil moisture was measured using a digital Lutron PMS714 soil moisture meter, and soil temperature was measured using a digital DT-801 (pen style) soil thermometer. All field parameters were collected in May and October in 2014, to sample the dry and wet seasons.

The experiment followed a split-plot design with 5 plots (combining land uses and location characteristics) as factor 1 and dolomite dosage as factor 2, nested within plots. The sites or farming systems consisted of: an oil palm farming system in peat reserve forest area in Mekar Jaya village (KS and BO plots); a rubber farming system outside the forest area in Teluk Nilau village (MS plot); a new farm derived from shrubs in Muntialo Jaya (HR plot); and a coffee farming system outside the forest area (KD plot).

Soil analysis Peat samples were collected in every plot from the depths of $0-10 \mathrm{~cm}$, $10-20 \mathrm{~cm}$, and $20-30 \mathrm{~cm}$, using a frame $(20 \mathrm{~cm} \times 20 \mathrm{~cm} \times 10 \mathrm{~cm}) \quad$ consecutively, with two replications. Peat samples were analyzed for chemical properties-soil acidity, macro nutrient contents, cation exchange capacity (CEC), base saturation (BS) and pyrite $\left(\mathrm{FeS}_{2}\right)$ content. Soil samples were analysed using standard procedures in the laboratory of the Soil Research Institute of the Ministry of Agriculture, Bogor, West Java province.

G. Organized linkages along the value chain

The value chain of jelutong was characterized and a strategy for jelutong development in Tanjabar, Jambi reported previously (Sofiyuddin et al. 2012). Farmers were interviewed for their prospects and expectations on the future of a jelutong tree planting.

Data analysis

Basic statistical analyses were conducted using IBM SPSS Statistics ver.22. Data were checked for 
homogeneity of variance and normality by analysis of residuals. A repeated measure procedure was applied to data on the survival, height and stem diameter growth of jelutong.

\section{Results and discussion}

\section{Steps A-B, D: history of Dyera polyphylla} domestication in Jambi

The diameter frequency distribution of the three natural jelutong stands in Tanjabar and Tanjabtim (Fig. 2) showed that jelutong was under threat, since the number of jelutong trees was lower than expected on the basis of earlier data of undisturbed stands. Due to the high rate of extraction of wood from the forests, which was confirmed by local informants, only 23 wild jelutong trees $\mathrm{ha}^{-1}$ were encountered in Tanjabar, while 60 wild jelutong trees ha ${ }^{-1}$ were encountered in the less accessible stand in Tanjabtim. The largest tree encountered in Tanjabatim had a dbh of $61.2 \mathrm{~cm}$, while in Tanjabar the largest tree only had a $\mathrm{dbh}$ of $46.5 \mathrm{~cm}$. Natural regeneration of D. polyphylla was evident as saplings (dbh less than $10 \mathrm{~cm}$ ). Our data can be compared to those of Kalima et al. (1998) who reported the natural distribution of D. polyphylla in Kanarakan, Kapuas district, Central Kalimantan province with a stand density 60 trees $\mathrm{ha}^{-1}$. Seedlings and young trees with a dbh less than $20 \mathrm{~cm}$ were not present in the 0.2 ha plots in the study area. The Jambi data suggested the depletion of stands, but still with active regeneration and opportunities for recovery.

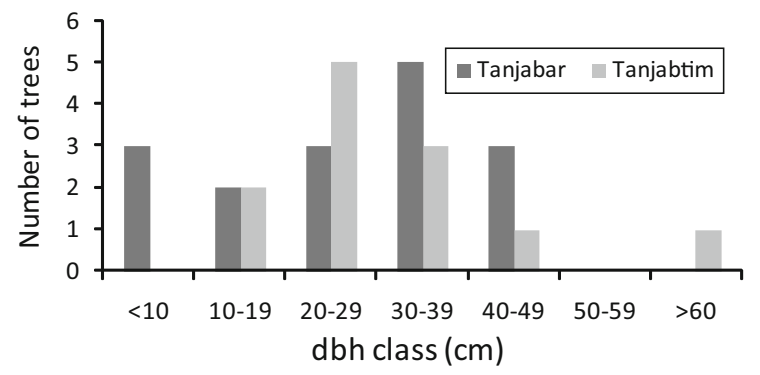

Fig. 2 Distribution of trees by dbh class of D. polyphylla in natural stands in Tanjung Jabung Barat and Tanjung Jabung Timur (tree density of 23 and 60 trees ha ${ }^{-1}$, respectively), in Jambi province, Indonesia
In Jambi province one company which had been granted a concession for plantation forestry (in Bahasa Indonesia it is known as hutan tanaman industri, HTI) based on planted $D$. polyphylla trees as a raw material for the pencil slate industry. It used seed collected from inside and outside the national park of Berbak, which is located about $25 \mathrm{~km}$ to the east of the plantation. The seeds were brought to the nursery and germinated, without purposeful selection. The first $D$. polyphylla seedlings were planted in 1992 on an area of 60 ha. Up to 1997, HTI planted 1769 ha of its total forest concession area of 9000 ha with jelutong. Jelutong grew well on the undrained peat, with basic forest management operations. In 1997, a severe peat forest fire burnt 7000 ha of the concession area, including the 1769 ha of jelutong plantation. In 2003, repeated fires affected about 5000 ha of the area and currently only about 200 ha of the plantation remains (Rosera anonymous; Subagyo pers. comm.).

Forest fires and peat forest fires in 1997/1998 resulted in extensive damage to the peatlands in Jambi province (Lubis and Suryadiputra 2004). Forest rehabilitation efforts started in 2002, under a reforestation fund program, which is obligatory for forest concession holders. In 2003, the movement for national forest rehabilitation in Indonesia ('Gerhan') was launched by the President of Indonesia, representing a top-down approach towards forest rehabilitation (Nawir et al. 2007). D. polyphylla was promoted as one of the species for peat forest rehabilitation in Sumatra and Kalimantan.

Efforts to rehabilitate the peat forest reserve in Tanjabar started in 2009 by planting jelutong seedlings on 500 ha as a program of the Forest District office. This program was continued in 2010 and 2011 and a total area of 840 ha of peat forest reserve was planted with jelutong under a mixed system with oil palm, aiming to phase out oil palm after its first production cycle (Agung et al. 2012)

In some areas in Tanjabar and Tanjabtim, located outside forest, ${ }^{1}$ people have initiated their own domestication process by developing nurseries and planting $D$. polyphylla in their peatlands. Three

\footnotetext{
${ }^{1}$ Forest is defined in Indonesia as an institutional domain of areas under the jurisdiction of the Ministry of Environments and Forestry; forest can be temporarily un-stocked as a result of human intervention, such as harvesting or natural causes but is expected to revert to full tree cover.
} 
respondents in Senyerang village of Tanjabar planted D. polyphylla in agroforestry systems, mixed with coconuts, Areca nuts, and rubber trees, while one respondent in Tanjabtim planted $D$. polyphylla in a monoculture system. Interestingly, two respondents in Senyerang village bought seedlings of $D$. polyphylla from a vendor, although the price of a seedling in 2005 was quite expensive (IDR 25,000 = USD 2.5), while others received seedlings from local government, for example form the Forest District office, through rehabilitation and/or afforestation programs. Two respondents from Senyerang were motivated to build a nursery and to germinate jelutong seeds by themselves. They collected jelutong seeds from residual stands of jelutong in the surrounding areas. On the other hand, a respondent from Rawa Sari knew how to handle and germinate jelutong seeds, as he learned it from the jelutong plantation of HTI mentioned earlier.

Steps A, C: Past practice on tapping

of and processing latex from natural habitats

Jelutong latex is a non-timber forest product with a long trading history, dating back to at least the mid nineteenth century. Tapping of jelutong latex in the forests is considered here as the start of the domestication process. Traditional tappers in Tanjabar shared unwritten but customary rules for tree tenure. Each tapper claimed individual rights to a number of tracks through the forest and a number of trees per track that could be tapped. The number of tracks ranged from 10 to 16 , while the number of trees per track ranged from 10 to 40 . These numbers varied depending on the density of jelutong trees in the forest and the number of tappers in a group. A similar customary form of tree tenure was reported in Lamandau, Central Kalimantan (Joshi et al. 2010; Janudianto et al. 2011). Half of our respondents who had experience in tapping jelutong were 33-72 year old. The tappers recognized individual jelutong trees that could produce a high volume of latex, based on the morphology of the bark and young shoots. The most desirable type is locally called 'jelutong mandi', and is characterized by a red young shoot and thin bark that is white blackish and smooth to somewhat rough. Jelutong with thick bark yields a small volume of latex according to local experience.
Tapping usually starts in the early morning at 6 A.M. Tappers use a special knife to tap latex in a V-shaped panel in the jelutong bark. The sap flows to the point of the V-shape, where a plastic bag is placed beneath the point of the V. In half a day (from 6 A.M. to 1 P.M.), a tapper could tap 10 to 40 trees in one track of jelutong trees, depending on expertise. On average, a tapper harvested $20 \mathrm{~kg}$ per 100 trees a day; this means that an average tree with one panel of tapping yielded $200 \mathrm{~g}$ latex a day. According to Williams (1963), the volume of latex yield depends on the method of tapping (the number and height of panels, and the extent of tapping). A tapper would return to the first track of jelutong trees after 10-16 days, depending on the number of lines that he claimed. During this resting period, the bark has time to recover before the next tapping.

Tappers sold latex to a middleman in the nearest village after a week of tapping. Prior to sale, the latex had to be processed which involved coagulation, boiling and pressing. Latex in a plastic bag is collected into a $25 \mathrm{l}$ jar and $5 \mathrm{~g}$ acetic acid as coagulant is added per 11 latex. Additional water reduces the quality of the latex (Williams 1963). In practice however, $50 \%$ of tappers added water to an equal volume of latex to increase the weight of the latex. The coagulated latex forms a cubical shape within one night which is then combined with hot water to enhance the hardening process. The cubical latex is pressed using a bottle or cylindrical pipe to remove water from the cube. The latex cube is then ready to be sold to a middleman. During the study period, no open markets for jelutong and rubber latex were available in Jambi for either jelutong or rubber latex.

Jelutong tapping volume from natural habitats in Jambi was recorded from 1986 to 2007, ranging from 0 to 1289.9 ton per year (BPS Provinsi Jambi 19862008), as shown in Fig. 3. Production of jelutong latex from natural habitats stopped in 2008 according to the statistics, while tappers reported stopped tapping jelutong latex from forests in 2006 after a national regulation on tariffs for non timber forest products extracted from forest areas has been launched. The respondents advised they were discouraged from tapping wild jelutong owing to the sanctions applied to illegal tappers of jelutong latex (Sofiyuddin et al. 2012; Agung et al. 2012). 
Fig. 3 Jelutong production in Jambi province, Indonesia 1985-2008 (data source BPS Jambi 1986-2008)

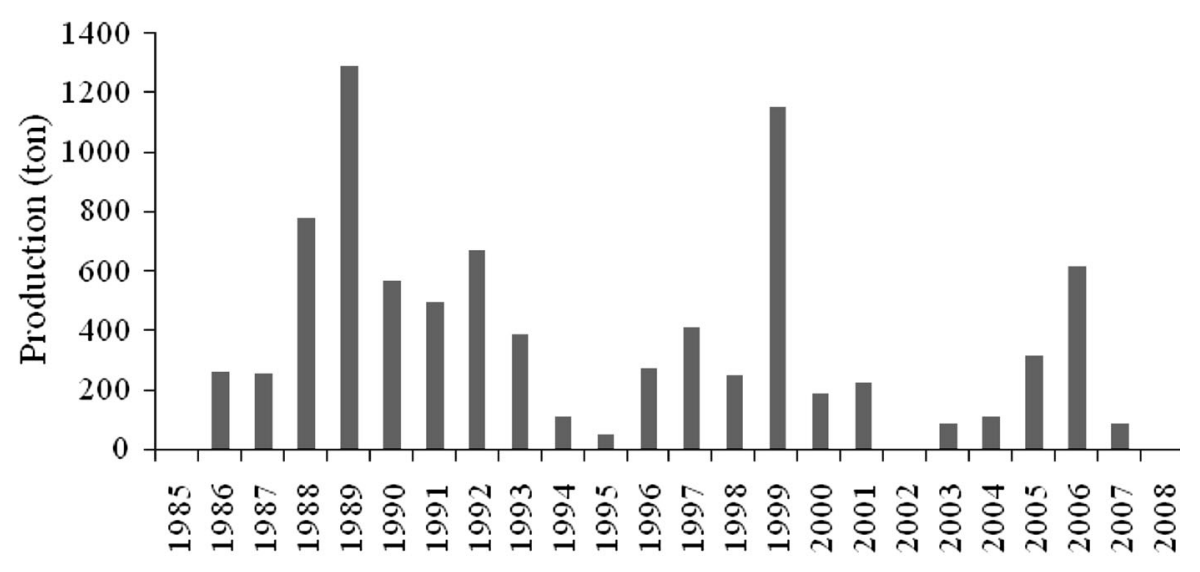

Year

Steps D1-D2: Current practices for jelutong cultivation

A further step in the domestication process includes cultivation outside the natural habitat. The initiation of jelutong planting by farmers was motivated by success stories on tapping jelutong in the wild. Six ex-tappers also cultivated jelutong, which implied a high level of motivation by the local people with regard to jelutong domestication. Of the respondents, $75 \%$ had experience in planting jelutong seedlings, and 7 out of 15 cultivators had experience in the germination of jelutong seeds. Four respondents had established their own nurseries. Two nurseries have received certificates from the Forest Seed Technology office (Balai Teknologi Perbenihan Hutan, BTPH) in Palembang, South Sumatra. Some respondents bought seedlings from seedling vendors. Most respondents received seedlings that were provided by the Forest District office; however, there was no financial support for planting and maintaining the planted seedlings. Extension officers were not present to guide the farmers in jelutong cultivation.

We measured the diameter of planted jelutong at 5 sites in Tanjabar and Tanjabtim, from 4 to 20 years after planting. The mean stem diameter in the different diameter classes ranged from 5.7 to $33.2 \mathrm{~cm}$ (Fig. 4). The diameter growth rate of jelutong varied from 1.3 to $1.9 \mathrm{~cm}_{\text {year }}{ }^{-1}$. Maintenance, particularly fencing, is one important factor that can improve the survival of jelutong. Wild pig (Sus scrofa) causes serious damage to the early growth of $D$. polyphylla $(0-5$ year after planting), because the pigs like to eat the stem of seedlings and the bark of young trees.

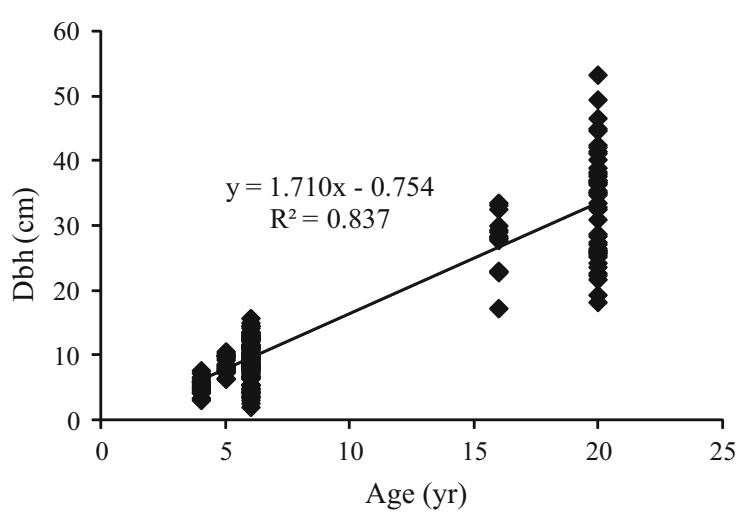

Fig. 4 Relationship between diameter at breast height (Dbh) and age of Dyera polyphylla planted in Tanjabar and Tanjabtim, Jambi province

The relationship between the diameter at breast height (Y) and age (X) of D. polyphylla in Jambi is linear and is represented by the equation $\mathrm{Y}=$ $1.710 \mathrm{X}-0.754$ (Fig. 4). This relationship implies that the mean annual increment (MAI) of diameter of D. pollyphylla is $1.7 \mathrm{~cm}$. Bastoni (2001) reported the MAI diameter for D. polyphylla at PT. DHL, Jambi, ranged from 1.1 to $2.4 \mathrm{~cm}$, consistent with our data.

Steps E-F: Growth of jelutong seedlings in the onfarm experiment

The survival and growth of jelutong planted in the 5 demo-plots was measured every 6 months for 4 successive measurements. The survival of jelutong planted in the 5 demo-plots varied with stand density. Seedlings in the BO plot (jelutong and oil palm) had 
the highest survival rate. Seedlings in the HR plot (jelutong derived from shrubs) declined rapidly to only $22 \%$ survival at 18 months after planting (Table 2). The jelutong seedlings in the HR plot competed with grasses and shrubs owing to reduced plot management, such as weeding and tending.

The BO and KS plots were relatively fertile with high $\mathrm{P}$ availability and exchangeable $\mathrm{Ca}$ levels, despite their low $\mathrm{pH}$ ranging from 3.5 to 4 (Table 3). The farmers of the BO and KS plots applied higher doses of phosphate fertilizer to induce fruit production, which also affected the growth of jelutong that were planted as an intercrop. Pyrite (sulphuric acid) levels were low in all plots.

Jelutong growth (diameter and height) in the 5 demo-plots was measured every 6 months (Table 4). The plots, based on different agroforest-based systems, significantly affected the growth of jelutong trees. Within sites, the MS plot (rubber and jelutong) had the lowest diameter and height growth, as it was less fertile (low high $\mathrm{P}$ availability and exchangeable Ca levels) than other sites. The BO and KS plots (oil palm and jelutong) had the highest growth at 12 and 18 MAP. At the last growth measurement, jelutong planted with oil palm in the BO and KS plots had mean stem diameter of 3.22 and $3.24 \mathrm{~cm}$, and mean heights of 163 and $159 \mathrm{~cm}$, respectively (Table 4). With large differences between plots in growth of diameter and height of jelutong (Tables 5 and 6), dolomite addition did not significantly affect growth of diameter (Table 5); it possibly did affect height growth $(\mathrm{P}<0.10)$ (Table 6). It was evident that jelutong without dolomite as a soil ameliorant grew well in acid peat soils. Dyera polyphylla is a native tree

Table 2 Survival of D. polyphylla seedlings in demo-plots for 4 separate observations over 18 months

\begin{tabular}{lclll}
\hline Plot & \multicolumn{4}{l}{ Survival $(\%)$} \\
\cline { 2 - 5 } & 0 MAP & 6 MAP & 12 MAP & 18 MAP \\
\hline HR & 100.0 & 82.9 & 55.0 & 22.1 \\
KD & 98.4 & 86.3 & 91.8 & 74.7 \\
MS & 100.0 & 98.1 & 95.6 & 87.5 \\
KS & 88.6 & 88.6 & 90.5 & 86.7 \\
BO & 99.0 & 96.4 & 94.8 & 90.2 \\
\hline
\end{tabular}

Note MAP months after planting, $H R$ jelutong, $K D$ jelutong + coffee, $M S$ jelutong + rubber, $K S \quad \& \quad B O$ jelutong + oil palm

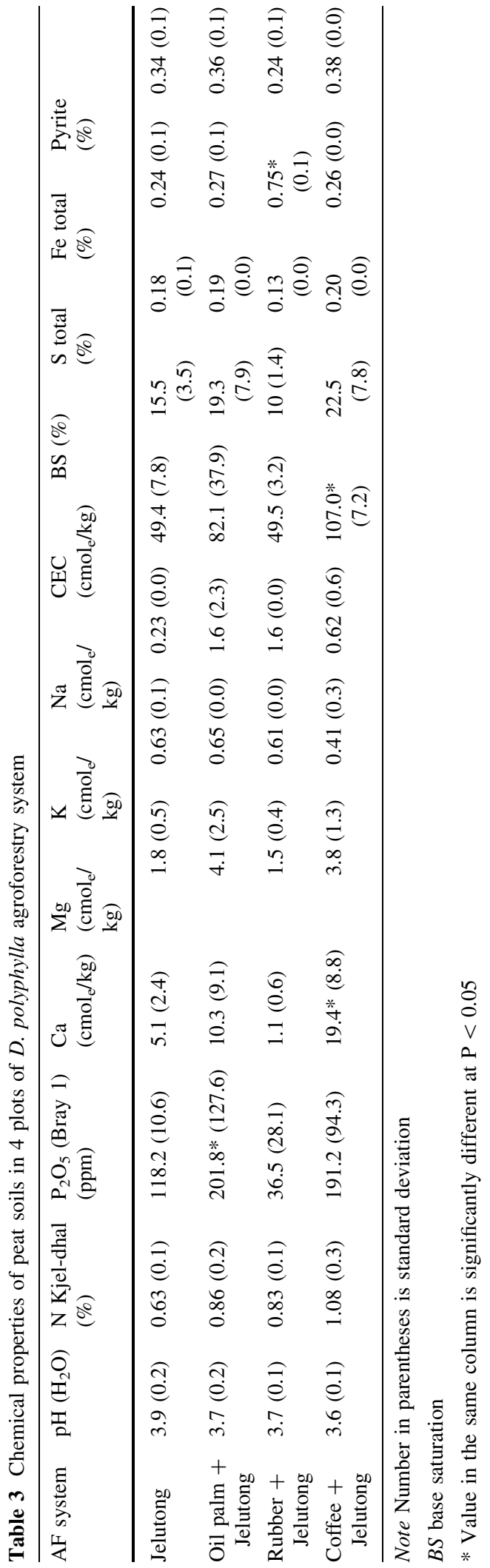


Table 4 Growth of jelutong (Dyera polyphylla) at different levels of dolomite for agroforestry system plots in Tanjung Jabung Barat, Jambi province

\begin{tabular}{|c|c|c|c|c|c|c|c|c|c|}
\hline Plot & Dolomite (g) & D_0 (cm) & D_6 (cm) & D_12 (cm) & D_18 (cm) & H_0 (cm) & H_6 (cm) & $\mathrm{H} \_12(\mathrm{~cm})$ & H_18 (cm) \\
\hline \multirow[t]{6}{*}{ BO } & 0 & $0.49(0.08)$ & $1.08(0.33)$ & $1.62(0.65)$ & $2.67(1.05)$ & $24.0(6.3)$ & $53.1(15.4)$ & $97.1(30.1)$ & $153.5(50.1)$ \\
\hline & 25 & $0.50(0.07)$ & $1.15(0.34)$ & $1.91(0.74)$ & $3.11(1.13)$ & $23.0(5.5)$ & $52.7(15.4)$ & $100.2(27.1)$ & $161.8(49.4)$ \\
\hline & 50 & $0.47(0.07)$ & $1.19(0.32)$ & $1.98(0.53)$ & $3.46(0.89)$ & $22.2(4.1)$ & $51.1(13.8)$ & $102.0(24.8)$ & $171.3(31.7)$ \\
\hline & 75 & $0.47(0.08)$ & $1.12(0.37)$ & $2.00(0.7)$ & $3.47(1.06)$ & 20.4 (3.9) & $47.2(13.2)$ & $102.8(35.1)$ & $173.5(54.2)$ \\
\hline & 100 & $0.49(0.1)$ & $1.04(0.35)$ & $1.80(0.5)$ & $3.72(4.44)$ & 22.7 (4.8) & $54.7(16.7)$ & $104.1(34.2)$ & $162.8(62.5)$ \\
\hline & Total & $0.48(0.08)$ & $1.11(0.32)$ & $1.84(0.65)$ & $3.22(2.04)$ & $22.6(5.3)$ & $51.8(15.0)$ & $100.7(30.1)$ & $163.4(50.2)$ \\
\hline \multirow[t]{6}{*}{$\mathrm{KS}$} & 0 & $0.57(0.09)$ & $1.02(0.37)$ & $1.88(0.77)$ & $3.47(1.35)$ & $28.2(4.7)$ & $50.7(22.0)$ & $102.5(45.8)$ & $161.6(59.9)$ \\
\hline & 25 & $0.57(0.08)$ & $1.09(0.40)$ & $1.74(0.74)$ & $3.25(1.03)$ & $30.0(4.8)$ & $49.6(18.3)$ & 85.3 (26.9) & $161.1(40.4)$ \\
\hline & 50 & $0.58(0.06)$ & $1.00(0.38)$ & $1.89(0.71)$ & $3.33(0.49)$ & 30.5 (4.9) & $50.5(20.4)$ & $106.3(32.8)$ & $183.9(40.4)$ \\
\hline & 75 & $0.53(0.05)$ & $1.08(0.54)$ & $1.95(0.67)$ & $3.17(1.27)$ & $31.2(3.3)$ & $49.0(11.4)$ & $103.6(25.1)$ & $153.4(63.4)$ \\
\hline & 100 & $0.55(0.1)$ & $0.90(0.29)$ & $1.50(0.44)$ & $2.93(1.2)$ & $29.1(6.5)$ & $39.9(9.2)$ & $79.7(23.0)$ & $140.4(48.6)$ \\
\hline & Total & $0.56(0.08)$ & $1.01(0.37)$ & $1.76(0.68)$ & $3.24(1.14)$ & $29.3(5.2)$ & $47.6(17.9)$ & $93.1(34.6)$ & $158.6(50.9)$ \\
\hline \multirow[t]{6}{*}{ HR } & 0 & $0.96(0.15)$ & $1.47(0.34)$ & $1.78(0.38)$ & $2.87(0.67)$ & $49.1(9.8)$ & $51.1(8.7)$ & $99.1(29.3)$ & $160.5(42.1)$ \\
\hline & 25 & $0.95(0.07)$ & $1.50(0.28)$ & $1.50(0.28)$ & $2.15(0.21)$ & $61.3(6.0)$ & $62.0(4.2)$ & $94.5(2.1)$ & $124.0(5.7)$ \\
\hline & 50 & $0.87(0.06)$ & $1.43(0.15)$ & $1.67(0.4)$ & $2.53(0.38)$ & $48.0(4.4)$ & $53.3(6.4)$ & $127.8(27.9)$ & $175.3(25.0)$ \\
\hline & 75 & $0.86(0.13)$ & $1.16(0.43)$ & $1.58(0.65)$ & $2.64(0.97)$ & $53.8(12.4)$ & $56.0(13.8)$ & 84.7 (33.7) & $130.2(49.1)$ \\
\hline & 100 & $0.94(0.15)$ & $1.51(0.2)$ & $2.01(0.73)$ & $2.29(0.65)$ & $49.5(11.4)$ & $52.3(11.0)$ & $93.0(29.2)$ & $135.4(48.7)$ \\
\hline & Total & $0.93(0.14)$ & $1.43(0.31)$ & $1.78(0.54)$ & $2.58(0.69)$ & $50.9(10.2)$ & 53.5 (9.9) & $97.4(29.2)$ & $145.8(43.5)$ \\
\hline \multirow[t]{6}{*}{ KD } & 0 & $0.80(0.2)$ & $1.16(0.32)$ & $1.42(0.4)$ & $1.57(0.51)$ & $40.9(7.8)$ & $59.1(15.9)$ & $88.0(31.0)$ & $126.6(57.1)$ \\
\hline & 25 & $0.89(0.2)$ & $1.24(0.37)$ & $1.41(0.5)$ & $1.52(0.61)$ & $43.9(8.7)$ & $62.1(16.8)$ & $88.0(34.3)$ & $126.3(56.7)$ \\
\hline & 50 & $0.87(0.14)$ & $1.11(0.31)$ & $1.37(0.41)$ & $1.43(0.76)$ & $39.1(8.8)$ & $59.5(15.6)$ & $88.5(33.3)$ & $111.1(50.5)$ \\
\hline & 75 & $0.85(0.3)$ & $1.10(0.31)$ & $1.22(0.32)$ & $1.46(0.42)$ & $43.2(6.4)$ & $54.1(12.5)$ & $74.3(23.0)$ & $105.9(44.0)$ \\
\hline & 100 & $0.75(0.2)$ & $0.92(0.18)$ & $1.08(0.35)$ & $1.25(0.45)$ & $34.6(7.8)$ & $48.6(12.3)$ & $72.6(21.3)$ & $106.5(45.0)$ \\
\hline & Total & $0.82(0.2)$ & $1.13(0.32)$ & $1.35(0.41)$ & $1.50(0.53)$ & $40.7(8.1)$ & $57.7(15.4)$ & $84.5(30.0)$ & $120.2(53.6)$ \\
\hline \multirow[t]{6}{*}{ MS } & 0 & $0.60(0.08)$ & $0.83(0.19)$ & $1.15(0.24)$ & $1.61(0.31)$ & $29.1(5.2)$ & $40.4(9.5)$ & $66.3(24.2)$ & $98.8(38.1)$ \\
\hline & 25 & $0.52(0.12)$ & $0.72(0.18)$ & $0.94(0.16)$ & $1.35(0.39)$ & $29.4(5.4)$ & $39.0(10.1)$ & $61.2(23.2)$ & $90.8(37.7)$ \\
\hline & 50 & $0.61(0.08)$ & $0.97(0.22)$ & $1.13(0.23)$ & $1.63(0.36)$ & $28.8(4.5)$ & $44.2(9.4)$ & 73.5 (21.8) & $105.6(30.7)$ \\
\hline & 75 & $0.56(0.09)$ & $0.73(0.15)$ & $1.00(0.17)$ & $1.45(0.33)$ & 30.4 (3.9) & $42.3(9.1)$ & $68.3(17.2)$ & 93.9 (26.6) \\
\hline & 100 & $0.58(0.14)$ & $0.73(0.17)$ & $1.01(0.21)$ & $1.48(0.34)$ & $33.0(6.7)$ & 45.7 (13.0) & $68.8(27.5)$ & $96.0(34.0)$ \\
\hline & Total & $0.57(0.11)$ & $0.79(0.2)$ & $1.04(0.22)$ & $1.50(0.36)$ & $30.1(5.3)$ & $42.3(10.4)$ & $67.7(23.0)$ & $97.0(33.5)$ \\
\hline
\end{tabular}

Note Numbers in parentheses show standard deviation. $D$ stem diameter, $H$ height, the consecutive numbers of $0,6,12,18$ following $\mathrm{D}$ and $\mathrm{H}$ represent age of seedling's age after it was planted (MAP), $B O \& K S$ jelutong and oil palm, $H R$ jelutong, $K D$ jelutong + coffee, $M S$ jelutong + rubber

species in peat swamp forest and so has evolved to adapt to acidic soils.

Farm management practices, such as weeding and fencing affected the survival and growth of jelutong. Minimum weeding, (circular weeding around seedlings) is necessary to minimize soil nutrient competition. However, over weeding could attract wild pigs to the seedlings. No disease attack was found in any of the demo-plots.

\section{G. Organized linkages along the value chain}

Farmer respondents believed that there will be market demand for jelutong latex, as long as a market for rubber latex is available, but the two markets follow separate dynamics. Linkages along the value chain of jelutong are currently less explored. In the national regulation (aka. Regulation of Ministry of Forestry no. 19 year 2009), jelutong is endorsed as a priority 
Table 5 Analysis of variance among subject effects on stem diameter of D. polyphylla seedlings

\begin{tabular}{lccrrr}
\hline Source & Type III sum of squares & Degrees of freedom & Mean square & F-test & Probability \\
\hline Intercept & 2188.520 & 1 & 2188.520 & 2728.930 & 0.000 \\
Plot & 188.892 & 4 & 47.223 & 58.884 & 0.000 \\
Dolomite & 1.599 & 4 & 0.400 & 0.499 & 0.737 \\
Plot $\times$ Dolomite & 18.498 & 16 & 1.156 & 1.442 \\
Error & 412.213 & 514 & 0.802 & 0.117 \\
\hline
\end{tabular}

Table 6 Analysis of variance among subject effects on height of D. polyphylla seedlings

\begin{tabular}{lccrrr}
\hline Source & Type III sum of squares & Degrees of freedom & Mean square & F-test & Probability \\
\hline Intercept & 6554508.904 & 1 & 6554508.904 & 3746.668 & 0.000 \\
Plot & 191401.292 & 4 & 47850.323 & 27.352 & 0.000 \\
Dolomite & 13818.549 & 4 & 3454.637 & 1.975 & 0.097 \\
Plot $\times$ Dolomite & 25371.796 & 15 & 1691.453 & 0.967 & 0.489 \\
Error & 881709.390 & 504 & 1749.423 & \\
\hline
\end{tabular}

species of non-timber forest products. Promoting wider use of jelutong and its product could improve interests of farmers and building a long term market. The resin derived from of jelutong latex has added value in the industry of bio-medicine as active pharmaceutical ingredients, which provides more economic benefit.

\section{Conclusions}

Our findings confirm evidence of all seven steps of the domestication process. The on-farm study showed that jelutong seedlings can be interplanted with many other tree crops, with appropriate management, such as suitable plant spacing and protection of seedlings from pests, particularly wild pig. Drainage is not required in the management of jelutong-based agroforestry. Dolomite as an ameliorant is not necessary for jelutong. Past and current efforts of jelutong domestication in Tanjabar and Tanjabtim are driven by local farmers, along with one larger-scale plantation. Current expectations of the potential for jelutong trees from agroforestry systems that are the basis of local governments' reforestation and afforestation programs are, however, not supported by data on current market demand. Farmers' motivation and initiation of jelutong domestication will have to be supported by national and local rules and regulations (Sofiyuddin et al. 2012; Mulia et al. 2013; Galudra et al. 2014) if further progress is to be made. The government would do well to ease the regulation on latex marketing that is still based on the assumption that all latex is derived from natural forests and should be taxed accordingly, in supporting farmers' initiatives in jelutong agroforestry, facilitating a value chain and ensuring competitive prices with other crops.

Acknowledgments This study was funded through a fellowship of the Women's Postdoctoral Program of The World Agroforestry Centre (ICRAF) to HLT and by Norwegian Agency for Development Cooperation (NORAD) through ASB-Secured Landscape Project. It is part of the CGIAR Research Program on Forests, Trees, and Agroforestry. We appreciate the comments received from Armand W. Mala and two anonymous reviewers. We thank Andrew J. Warner for improving the English.

Open Access This article is distributed under the terms of the Creative Commons Attribution 4.0 International License (http:// creativecommons.org/licenses/by/4.0/), which permits unrestricted use, distribution, and reproduction in any medium, provided you give appropriate credit to the original author(s) and the source, provide a link to the Creative Commons license, and indicate if changes were made.

\section{References}

Agung P, Novia CY, Jasnari, Galudra G (2012) Menuju pengelolaan hutan lindung gambut lestari di tanjung Jabung Barat, Indonesia. World Agroforestry Centre-ICRAF, SEA Regional Office. Bogor, Indonesia. Brief No. 24 
Bastoni (2001) Teknik rehabilitasi hutan rawa gambut bekas terbakar. In: Anonymous (ed) Prosiding Ekspose Hasilhasil Penelitian Balai Teknologi Rehabilitasi Palembang. Pusat Penelitian dan Pengembangan Hutan dan Konservasi Alam. Badan Penelitian dan Pengembangan Kehutanan. Departemen Kehutanan, Bogor. pp 39-52

BPS [Badan Pusat Statistik] (1986-2008) Jambi Dalam Angka 1986-2008. Badan Pusat Statistik Jambi. Jambi

Franton J (1996) The tree improvement process. Limbs \& Needles 23(4):10,12,14

Galudra G, van Noordwijk M, Agung P, Suyanto S, Pradhan U (2014) Migrants, land markets and carbon emissions in Jambi, Indonesia: land tenure change and the prospect of emission reduction. Mitig Adapt Strateg Glob Change 19(6):715-732

Herrera CM (2002) Seed dispersal by vertebrates. In: Herrera CM, Pellmy O (eds) Plant animal interactions: an evolutionary approach. Blackwell Science, Oxford, pp 185-208

Janudianto, Mulyoutami E, Joshi L, Wardell DA, van Noordwijk M (2011) Recognizing traditional tree tenure as part of conservation and REDD + strategy: Feasibility study for a buffer zone between a wildlife reserve and the Lamandau river in Indonesia's REDD + Pilot Province. ASB Policy brief 22. ASB Partnership for the Tropical Forest Margins, Nairobi, Kenya

Jayanthy T, Sankanarayanan PE (2005) Measurement of dry rubber content on latex using microwave technique. Measur Sci Rev 5(3):50-54

Joshi L, Janudianto, van Noordwijk M, Pradhan U (2010) Investment in carbon stocks in the eastern buffer zone of Lamandau River Wildlife Reserve, Central Kalimantan province, Indonesia: a REDD + feasibility study. Project Report. World Agroforestry Centre (ICRAF) Southeast Asia Regional Office, Bogor

Joshi L, van Noordwijk M, Martini E, Janudianto (2013) Rapid appraisal of agroforestry practices, systems and technology RAFT. In: van Noordwijk M, Lusiana B, Leimona B, Dewi S, Wulandari D (eds). Negotiation-support toolkit for learning landscapes. Bogor, Indonesia. World Agroforestry Centre (ICRAF) Southeast Asia Regional Program. pp 36-42

Kalima T, Setyawati T, Carman H, Anggana (1998) Some ecological aspects of jelutung (Dyera polyphylla Hk.f). Bul Penelit Hutan 611:35-46

Larson G, Piperno DR, Allaby RG, Puruggana MD, Andersson Leif, Arroyo-Kalin M, Barton L, Viguera CC, Denham T, Dobney K, Doust AN, Gepts P, Gilbert TP, Gremillion KJ, Lukens L, Marshall FB, Olsen KM, Pires JC, Richerson PJ, de Casas RR, Sanjur OI, Thomas MG, Fuller DQ (2014) Current perspectives and the future of domestication studies. PNAS 11(17):6139-6146

Leakey RRB, Tchoundjeu Z, Smith RI, Munro RC, Fondoun JM, Kengue J, Anegbeh PO, Atangana AR, Waruhiu AN, Asaah E, Usoro C, Ukafor V (2004) Evidence that subsistence farmers have domesticated indigenous fruits (Dacryodes edulis and Irvingia gabonensis) in Cameroon and Nigeria. Agrofor Syst 60:101-111

Lemmens RHMJ, Soerianegara I, Wong WC (1995) Timber trees: Minor commercial timbers. Plant Resources of Southeast Asia No. 5.2. Backhuys Publishers, Leiden

Lubis IR, Suryadiputra INN (2004) Upaya pengelolaan terpadu hutan rawa gambut bekas terbakar di wilayah Berbak-
Sembilang. In: Suyanto, Chokkalingam U, Wibowo P. (eds). Kebakaran di lahan rawa/gambut di Sumatera: Masalah dan solusi. Prosiding Semiloka. CIFOR, Bogor, pp 105-119

Markl JS, Schleuning M, Forget PM, Jordano P, Lambert JE, Traveset A, Wright SJ, Böhning-Gaese K (2012) Metaanalysis of the effects of human disturbance on seed dispersal by animals. Conser Biol 26(6):1072-1081

Martini E, Roshetko JM, van Noordwijk M, Rahmanulloh A, Mulyoutami E, Joshi L, Budidarsono S (2012) Sugar palm (Arenga pinnata Wurmb) Merr for livelihoods and biodiversity conservation in the orang-utan habitat of Batang Toru, North Sumatra, Indonesia: mixed prospects for domestication. Agroforest Syst 86:401-417

Meyer RS, Purugganan MD (2013) Evolution of crop species: genetics of domestication and diversification. Nature 14:840-852

Michon G, De Foresta H (1996) Agroforests as an alternative to pure plantations for the domestication and commercialization of NTFPs. In: Leakey RRB, Temu AB, Melnyk M, Vantomme P (eds) Domestication and commercialization of non-timber forest products in agroforestry systems. FAO, Rome, pp 160-175

Middleton D (2004) Dyera. In: Soepadmo E, Saw LG, Chung RCK (eds). Tree flora of Sabar and Sarawak. Vol. 52004. Sabah Forestry Department, Forest Research Institute Malaysia, Sarawak Forestry Department. Malaysia. Kuala Lumpur, Malaysia, pp 27-30

Mpanda M, Munjuga M, Reyes T, Said A, Rutatina F, Kimaro A, van Noordwijk M (2014) Allanblackia, Butterflies and Cardamom: sustaining livelihoods alongside biodiversity conservation on the forest-agroforestry interface in the East Usambara Mountains, Tanzania. Trees Livelihoods 23:127-142

Mulia R, Widyata A, Suyanto Agung P, Zulkarnain MT (2013) Low carbon emission development strategies for Jambi, Indonesia: simulation and trade off analysis using the FALLOW model. Mitig Adapt Strateg Glob Change. doi:10.1007/s11027-013-9485-8

Nawir AA, Murniati, Rumboko (2007) Forest rehabilitation in Indonesia: Where to go after more than three decades? Center for International Forestry Research (CIFOR), Bogor, Indonesia. $269 \mathrm{pp}$

Ordonez JC, Luedeling E, Kindt R, Tata HL, Harja D, Jamnadass R, van Noordwijk M (2014) Tree diversity along the forest transition curve: drivers, consequences and entry points for multifunctional agriculture. Curr Opin Environ Sustain 6:54-60

Prance GT (1994) Amazonian tree diversity and the potential for supply of non-timber forest products. In: Leakey RRB, Newton AC (eds) Tropical trees: the potential for domestication and the rebuilding of forest resources. HMSO, London, pp 7-15

Ritung S, Wahyunto, Nugroho K, Sukarman, Hikmatullah, Suparto, Tafakresnanto C (2011) Peta Lahan Gambut Indonesia skala 1:250.000. Balai Besar Penelitian dan Pengembangan Sumberdaya Lahan Pertanian. Badan Penelitian dan Pengembangan Pertanian. Bogor, Indonesia

Roshetko JM, Evans DO (eds) (1999) Domestication of Agroforestry Trees in Southeast Asia. Forest, Farm, and Community Tree Research Reports, special issue

Santos-Martın F, Bertomeu M, van Noordwijk M, Navarro R (2011) Understanding forest transition in the Philippines: 
main farm-level factors influencing smallholder's capacity and intention to plant native timber trees. Small-scale For. doi:10.1007/s11842-011-9166-y

Schreckenberg K, Awono A, Degrande A, Mbosso C, Ndoye O, Tchoundjeu Z (2006) Domesticating indigenous fruit trees as a contribution to poverty reduction. For Trees Livelihoods 16:35-51

Simons AJ (1996) ICRAF's strategy for domestication of nonwood tree products. In: Leakey RRB, Temu AB, Melnyk $\mathrm{M}$, Vantomme P (eds) Domestication and commercialization of non-timber forest products in agroforestry systems. Proceedings of an international conference, FAO, Rome, pp 8-22

Simons AJ, Leakey RRB (2004) Tree domestication in tropical agroforestry. Agrofor Syst 61:167-181

Sofiyuddin M, Janudianto, Perdana A (2012) Potensi pengembangan dan pemasaran jelutung di Tanjung Jabung Barat, Indonesia. World Agroforestry Centre-ICRAF, SEA Regional Office. Brief no. 23

van Noordwijk M, Villamor GB (2014) Tree cover transitions in tropical landscapes: hypotheses and cross-continental synthesis. In: Minang PA, van Noordwijk M, Kahurani E (eds) Partnership in the tropical forest margins: a 20-year journey in search of alternatives to Slash-and-Burn. Nairobi, ICRAF, pp 17-22 van Noordwijk M, Tata HL, Xu J, Dewi S, Minang P (2012) Segregate or integrate for multifunctionality and sustained change through landscape agroforestry involving rubber in Indonesia and China. In: Nair PKR, Garrity DP (eds) Agroforestry: the future of global landuse. Springer, Dordrecht, pp 69-104

van Noordwijk M, Matthews R, Agus F, Farmer J, Verchot L, Hergoualc' $h \mathrm{~K}$ et al (2014) Mud, muddle and models in the knowledge value-chain to action on tropical peatland conservation. Mitig Adapt Strateg Glob Change 19(6):887-905

Wiersum KF (1996) Domestication of valuable tree species in agroforestry systems: evolutionary stages from gathering to breeding. In: Leakey RRB, Temu AB, Melnyk M, Vantomme P (eds) Domestication and commercialization of non-timber forest products in agroforestry systems. Proceedings of an international conference. FAO, Rome, pp 147-157

Williams L (1963) Lactiferous plant of economic importance IV jelutong (Dyera sp). Economic Botany, Vol 17, No. 2. New York Botanical Garden Press

Rosera H (anonymous) Pengalaman PT Dyera Hutan Lestari (DHL) dalam pengembangan hutan tanaman industry di areal lahan gambut. In: Climate Change, Forest and Peatlands in Indonesia. Wetlands International Indonesia, Bogor 